\title{
Nova Titular de Direito Processual Penal nas Arcadas: Ada Pellegrini Grinover
}

\begin{abstract}
Tendo conquistado com brilhantismo a titularidade da Cadeira de Direito Processual Penal, em concurso realizado em setembro de 1980, foi recebida solenemente pela Congregação a Professora ADA PELLEgrini Grinover.

No dia 5 de novembro de 1980 , às 8,30 horas, no Salão Nobre, estando reunida a Congregaça, a nova Titular foi introduzida no Doutoral pelo Professor Emérito JoAquim Canuto Mendes de Almema, seu antecessor, e pelos Professores Silvio Rodrigues e JosE Afonso da Silva.

Saudou a Professora Ada o Professor Manoel Goncalves FERreira FilHo, que tracou a biografia da nova Titular, decantando suas qualidades: sua profunda inteligência, seus esforços, tenacidade e criatividade, que culminaram com a conquista de mais alto galardão do magistério superior, tudo por seus próprios méritos.

Num comovente discurso, a Professora ADA agradeceu a homenagem e reafirmou seus propósitos de lutar sempre mais, pela glória da Academia, como fez até agora, e pelo brilho da Ciência Processual Penal, e o fez consciente da imperiosa necessidade da formação de uma nova escola de processualistas, formada com as grandes figuras de nosso Direito Processual Penal, para edifić́-lo à altura das conquistas do Processo Civil.
\end{abstract}

\section{A Segunda Titular das Arcadas}

A Professora AdA Pellegrini GRINover nasceu na Itália, de uma família de eminentes magistrados. Seu pai, Domenico Pellegrini Giampietro, intelectual e jurista, lecionava Direito Constitucional italiano e comparado, além de Teoria Geral do Estado, na Faculdade de Direito da Universidade de Nápoles, e regia Direito Público Comparado na Faculdade de Ciências Políticas da Universidade de Roma.

Com a situação política italiana do pós-guerra, a família emigrou, em 1951, para o Brasil, e foi nessa data que a Doutora ADA chegou à nossa terra.

Ela veio, já com a sólida base cultural adquirida na Europa, terminar o curso clássico no Colégio Dante Alighieri.

Em 1953 prestou vestibular para a Faculdade de Direito, onde classificou-se em $3 .^{\circ}$ lugar. Foi um dos melhores alunos de sua turma, obtendo, em 1956, o prêmio Basileu Garcia, como melhor estudante de Direito Penal.

Formada em 1957, a nova Titular desenvolveu intensa atividade profissional. Sendo nomeada Procuradora do Estado, 
foi assessora jurídica do vice-Governador do Estado, e chefe da Consultoria Jurídica da Secretaria de Justiça.

A Doutora ADA fez o curso de especialização em Direito Processual Civil em 1966, obtendo média 10, e em 1970 recebeu o grau de Doutor em Ciências Jurídicas e Sociais, também com a nota máxima, apresentando a tese: Ação Declaratória Incidental.

Em 1969 assumiu a função de professora assistente de Direito Constitucional na Pontifícia Universidade Católica de São Paulo.

Em nossa Faculdade iniciou sua carreira de docente em 1971, colaborando nos cursos de Direito Constitucional e Processo, como Professora Assistente Doutora.

Em 1973, em brilhante concurso, alcançou a Livre Docência, com o trabalho: As Garantias Constitucionais do Direito de Ação e sua Relevância no Processo Civil. Nesse mesmo ano, em concurso no âmbito do Departamento de Direito do Estado, conquistou o título de Professor Adjunto, e no Departamento de Direito Processual repetiu o feito, sempre com a nota máxima.

Nos cursos de graduação, a Professora ADA lecionou, pois, Direito Processual Civil, Direito Processual Penal e, no Pós-Graduação, Liberdades Públicas.

Ao lado de todas essas atividades docentes e profissionais, a Doutora ADA escreveu uma série de livros e artigos, fornecendo uma importante contribuição à Ciência Processual.

\section{Bibliografia.}

1. Ação Declaratória Incidental.

2. As Garantias Constitucionais do Direito de Ação

3. Direito Processual Civil.

4. Teoria Geral do Processo (em colaboração com os Professores ANtonio Carlos de araújo Cunha e Cândido Rangel Dinamarco.

5. Os princípios constitucionais e o Código de Processo Civil.

6. O Processo em sua Unidade.

7. As Condiçōes de Ação Penal.

8. Eficácia e Autoridade da Sentença Penal.

9. Liberdades Públicas (em colaboração com os Professores Manoel Gonçalves Ferreira Filho e Anna CÂndida da Cunha Ferraz.

10. Liberdades Públicas e Processo Penal.

11. Interceptaçōes Telefônicas.

\section{A. Posse}

No dia 5 de novembro de 1980 , reuniu-se a Congregação dos Professores, no Salão Nobre da Faculdade de Direito, para 
recepcionar a nova Professora Titular de Direito Processual Penal, Doutora ADA PELLEGRINI GRINOVER.

Estavam presentes à cerimônia a Diretora em exercício, Doutora NAIR LEMOS GoNÇALVES, a primeira Titular da Academia; a Secretária, Doutora DRINADIR COELHO, grandes figuras da sociedade jurídica nacional, alunos, amigos e familiares da nova Titular.

O Professor Emérito Joaquim Canuto Mendes DE ALMEIDA, juntamente com os professores SILvio RoDRIGUES e José AFonso DA SILVA, introduziram a nova Titular no Doutoral.

O Professor Manoel Gonçalves Ferreira Filho fez uma bela saudação, abordando os fatos principais da brilhante carreira docente da Professora ADA, exaltando suas qualidades pessoais e culturais, sua preclara inteligência, grande tenacidade e espírito de luta.

Refere-se à profícua produção de importantes obras no campo do Direito Processual, dizendo "soubestes, timbro em sublinhar, nessas obras, combinar uma pesquisa original com as lições dos grandes mestres. Aproveitastes não só os estágios e pesquisas que fizestes no Instituto de Direito Público da Universidade de Pádua e no Instituto de Direito Processual Penal da Universidade de Pavia, junto a mestres como Aldo ATTARDI e MARIO PISANI, como soubestes apreender como poucos as lições fundamentais de eméritos processualistas como Luís EUlálio DE BUENo VIDIGAL, AlFRedo BUZAID, Celso Neves e vosso antecessor CANUto MENDES DE ALMEIDA"

No discurso de agradecimento a Nova Titular explica o que significa para ela a conquista do mais alto grau na carreira universitária: "Ser professor titular desta Casa significa a inserção concreta nessa Douta Congregação, ou seja a participação integral e definitiva, pelo cargo mais elevado da carreira, em uma instituição secular, que tem entre os seus valores fundantes os melhores valores da própria sociedade: o humanismo, o vigor e a coragem das idéias, a luta pelo direito, pela justiça e pela liberdade"

Afirmou ainda que o importante agora é o que dela se espera em atitudes e gestos, em palavras futuras, em comportamento e conduta, e reafirmou seus propósitos de lutar cada vez mais, como sempre fez até a presente data, pela glória da Academia e pelo brilho da Ciência Processual Penal, consciente da necessidade de seu desenvolvimento, com a formação de uma nova escola paulista de processualistas, para edificar o Processo Penal à altura das conquistas do Processo Civil. 


\section{Saudação de Manoel Gonçalves Ferreira Filho}

Mais uma vez, na continuidade de suas tradições, reúne-se a Congregação da Faculdade de Direito para receber um novo Professor Titular. Esta é a vossa vez, Profa. AdA PELLEgrini GRINOVER, vez que conquistastes com esforço, mérito indisputável e, por que não dizê-lo, lágrimas de sacrifício.

Solene é a cerimônia. Mantém-se, com todo o formalismo, o ritual. Presentes no doutoral os professores, becas negras, cinturas vermelhas. À sua frente, o Diretor, hoje como que simbolicamente a ilustre Diretora em exercício, primus inter pares a reger, segura, os atos prescritos. Em face, ocupando o salão nobre, uma brilhante sociedade de juristas e amigos. E, um pouco por toda a parte, os estudantes do Largo de São Francisco, atentos, ágeis, entre emocionados e irônicos diante de tamanha pompa.

Tanta solenidade causa sempre espécie. Numa época em que o informalismo foi erigido em regra, a muitos choca a permanência de tal estilo. Pior, numa época em que o desalinho passa senão por elegância pelo menos por sinal de intelectualidade, o atavio parece ranço.

Entretanto, o caráter solene desta cerimônia tem sua razão de ser. Reflete uma tradição que há de ser preservada. Sublinha o fato de que a posse na Congregação do Largo de São Francisco significa mais, e bem mais, do que o acesso a um cargo público. Não é apenas galgar o mais alto nível funcional na Universidade brasileira, é pertencer a uma instituição que tem história.

Vão além de cento e cinqüenta os anos de existência da Academia. Isto não seria muito para os padrões europeus, habituados a instituições multisseculares. É um longo tempo no Brasil onde tudo é novo, recente. Já bastaria isto para assinalar a especificidade desta Casa, em face de outras escolas que a cercam. Mas não é o mero decurso do tempo que fala. Eloqüência maior tem a obra da Faculdade.

Duas são as faces desta. Uma é estritamente jurídica. Resulta da produção dos jurisconsultos que nela ensinaram e estudaram, dos homens do Direito que nela aprenderam a cultivar a ciência das leis e a cuituar a filosofia da Justiça.

A outra, é cívica. Reflete o amor e o devotamento à Pátria que as próprias paredes das. Arcadas incutem em mestres e discípulos. Nisto, quiçá, de novo pareça desatualizada a Faculdade. No tempo dos jeans e das camisetas, somente nesta velha 
Casa ousaria alguém ainda falar de Pátria. Os modernizados reservam o seu entusiasmo para outros conceitos, que dividem e antagonizam. Preferem classe a pátria, proletariado a povo.

Repita-se, recorde-se, porém, a lição de RUI: "A Pátria não é ninguém: são todos; e cada qual tem no seio dela o mesmo direito à idéia, à palavra, à associação. A Pátria não é um sistema; nem uma seita, nem um monopólio, nem uma forma de governo: é o céu, o solo, o povo, a tradição, a consciência, o lar, o berço dos filhos e o túmulo dos antepassados, a comunhão da lei, da língua e da liberdade. Os que a servem, são os que não invejam, os que não infamam, os que não conspiram, os que não sublevam, os que não desalentam, os que não emudecem, os que não se acobardam, mas resistem, mas ensinam, mas esforçam, mas pacificam, mas discutem, mas praticam a justiça, a admiração, o entusiasmo"

Esta é a verdadeira tradição política da Faculdade do Largo de São Francisco. Não o facciosismo partidário, não a paixão irresponsável, não o fanatismo irracional, não o apelo à liberdade na desordem nem o anhelo da ordem sob a escravidão. Mas o civismo e o patriotismo, sempre e em cada momento.

Foi isto que aprendemos, Profa. AdA Pellegrini Grinover, já em 1953 quando viemos a cursar as lições desta Faculdade. Vinha eu de perto, paulista que sou, não há quatrocentos anos que me falta o brasão aristocrático, mas há noventa que a tanto data a imigração de meus avós. Chegáveis de longe, deixando a bela e nobre terra de vossos ancestrais.

Muitas penas, muitos sacrifícios, muitas provações vos custaram esta emigração. Nascida que fostes na Itália, de uma família de magistrados eminentes, nada vos anunciava, nada vos propunha o abandono da terra natal. Ao contrário, tudo vos prenunciava um futuro tranqüilo, a que vossa rara inteligência saberia dar fulgor.

A guerra, contudo, toldou esse horizonte. A guerra? Ou melhor dizendo, o patriotismo de vosso pai. Domenico PelleGRINI GIAMPIETRo era daqueles para os quais da Pátria nada se pede e a ela tudo se dá. Lutara pela Itália na primeira Guerra Mundial, com denodo e valor, sendo por isso três vezes condecorado e duas vezes promovido por merecimento. Intelectual e jurista de escol, ensinara Direito Constitucional italiano e comparado, bem como Teoria Geral do Estado na Faculdade de Direito da Universidade de Nápoles, regera Direito Público Comparado na Faculdade de Ciências Políticas da Universidade 
de Roma, publicara inúmeras obras. Podia ter-se encolhido num canto abrigado enquanto se desencadeava a tormenta que foi a segunda Guerra Mundial. Não era esse o seu feitio, porém: movido pelo sentido do dever cívico, aceitou em 1943 o Ministério da Fazenda, quando a Itália passava por grave crise. Nesse instante histórico, o poder já aparecia despido de atrativos, era o trabalho ingrato com a promessa, certa e inexorável, da incompreensão futura.

E esta incompreensão, tão fácil de prever, ocorreu com o fịm da guerra. A paixão dos adversários, mormente dos que, após o triunfo, precisavam redimir-se das omissões e acomodações em que tinham até então vivido, contra ele se voltou. Corajosamente compareceu então, de modo espontâneo, perante os acusadores. Foi processado e condenado pelo crime político de colaboração. Entretanto, apreciando recurso, em outubro de 1946, a Corte Suprema anulou a sentença, reconhecendo que toda a sua obra como Ministro "foi no sentido de obstacular o programa alemão", que encarava a Itália como país conquistado e seu patrimônio como presa bélica, a fim de preservar, na medida do possível, as reservas financeiras e os recursos econômicos italianos.

Os reflexos dessa situação, todavia, o impeliram a vir para a América. Primeiro para o Brasil, em 1949, e aqui fundou o Banco do Trabalho ftalo-Brasileiro. Depois, para o Uruguai, onde veio a falecer. Em 1951, pôde chamar para junto de si a família. Com ela viestes, cara Professora.

Permiti-me que retrace para o auditório a vossa biografia.

Já possuíeis, então, a base cultural que, na Europa, os estudos secundários sabem infundir. Aqui viestes a cursar o Colégio Dante Alighieri. Neste, cumpristes o currículo das $2 .{ }^{a} \mathrm{~S}$ e $3 .^{a} \mathrm{~S}$ séries do Clássico, sempre recompensada nos vossos esforços com o primeiro lugar e bolsa de estudos. Em 1953, prestastes vestibular para esta Faculdade, tendo alcançado o terceiro lugar. Destacando-vos, durante todo o curso jurídico, mostrastes ser um dos melhores alunos da turma, alcançando em 1956 o prêmio "Basileu Garcia" como melhor estudante de Direito Penal. Igualmente revelastes, desde cedo, forte inclinação para os estudos processuais, motivada e orientada, sem dúvida, pelo insigne Prof. Lú́s Eulálio de BUENo VIDIGaL que era, como é, para todos os seus discípulos o exemplo de jurisconsulto e de mestre culto e devotado. Deste exemplo, sublinhe-se num parêntese, veio certamente a vocação para o ensino, tão difundida entre seus alunos, conso hoje prova o doutoral. 
Formada em 1957, cara Profa. AdA PELLEGRINI GRINover, passastes a desenvolver uma intensa atividade profissional. Isto, porém, não vos impediu de, casando, assumir os encargos do lar bem como o de cuidar e educar um filho, atualmente estudante de engenharia.

De fato, passastes a advogar com brilho e tenacidade como ainda o fazeis, agora como procuradora do Estado. E, já investida nesta qualidade, fostes assessora jurídica do vice-governador do Estado e chefe da Consultoria Jurídica da Secretaria da Justiça, dentre outros postos de relevo.

O êxito na advocacia, contudo, não vos sufocou o pendor para estudos aprofundados. Obtivestes a especialização em Direito Processual Civil, com média dez, em 1966, alcançastes o grau de Doutor em Ciências Jurídicas e Sociais, em 1970, com a tese $A c ̧ \tilde{a} o$ Declaratória Incidental, que vos valeu outra média dez, sempre nesta Faculdade.

Um pouco antes já havíeis iniciado a carreira didática. Com efeito, em 1969, assumistes as funções de assistente da disciplina Direito Constitucional, na Faculdade de Direito da Pontifícia Universidade Católica. Começáveis a mostrar a inclinação típica de vosso talento que já vos marcou o lugar e a originalidade no seio da eminente Escola Paulista de processualistas. A preocupação de embasar as lições e as tecnicidades do Processo Civil e Penal no leito profundo do Direito Constitucional.

E foi colaborando com os cursos de Direito Constitucional e de Processo que iniciastes em 1971 a vossa carreira nesta casa, como Professora Assistente Doutora. Conquistastes desde logo o respeito dos colegas, a admiração dos alunos, o talento demonstrado no ensino e na pesquisa. Em 1973, em brilhante concurso, alcançastes a livre-docência, com o trabalho As garantias constitucionais do Direito de Ação e sua relevância no processo civil. $\mathrm{Em}$ agosto de 1976 , em concurso no âmbito do Departamento de Direito do Estado, chegastes a Professora Adjunta, com mais uma média dez. Em dezembro do mesmo ano, repetistes a façanha, agora no Departamento de Direito Processual, sempre com a média máxima.

Embora profundamente dedicada ao ensino, dando aulas de Processo Civil, Processo Penal e ministrando no Pós Graduação a disciplina Liberdades Públicas, encontrastes tempo para produzir vários livros e incontáveis artigos. Assim, publicastes, entre outros, os livros Direito Processual Civil, Teoria Geral do Processo (este em colaboração com os Professores ANTônio 
Carlos de Araújo Cintra e Cândido Rangel Dinamarco), Os principios constitucionais e o Código de Processo Civil, $O$ processo em sua unidade, Eficácia e Autoridade da sentença penal e Liberdades Públicas (este com a minha participação e a da Professora Assistente ANNa CÂNDIDA DA CUNHA FERraZ).

Soubestes, timbro em sublinhar, nessas obras combinar uma pesquisa original com as lições dos grandes mestres. Aproveitastes não só os estágios e pesquisas que fizestes no Instituto de Direito Público da Universidade de Pádua e no Instituto de Direito Processual Penal da Universidade de Pavia, junto a mestres como ALDo ATTARDi e MARIo PISANI, como soubestes apreender como poucos as lições fundamentais de eméritos processualistas como LUÍs EULÁLIO DE BUENO VIDIGAL, Alfredo BuzaId, Celso Neves e vosso antecessor Canuto MENDES DE ALMEIDA.

Ereis, por isso, candidata lógica a ocupar a vaga que iria deixar, por força da aposentadoria compulsória, o nosso querido professor, mestre JoAQUIM CANUTO MENDES DE ALMEIDA. Quem conhecia o vosso talento e não ignorava a extensão de vossos conhecimentos, tinha a convicção tranqüila de que venceríeis o concurso. 0 livro que escrevestes para a disputa, Liberdades Públicas e Processo Penal: as interceptações telefônicas, confirmava essa impressão.

Esta mesma convicção, Profa. AdA Pellegrini Grinover, dominou os que se vos antepunham. E triste contingência, decorrente da imperfeição humana, que o mérito atraia hostilidade. O sentimento recôndito de inferioridade provoca insopitáveis manifestações de inveja e mesquinharia, incontáveis tramas destinadas a destruir a obra alheia. Lamentavelmente isto ocorreu e mesmo nesta Casa. Não é o momento de recordar os amargos momentos que vivestes. $\mathrm{E}$ vencestes.

Sim, e vencestes. E que vitória a vossa. Obtivestes da Banca o primeiro lugar, por unanimidade, no concurso, o que corroborou a douta Congregação. Lograstes ver sepultadas as acusações iníquas contra vós formuladas, por uma comissão examinadora que tinha a integrá-la mestres como, não citando os da Casa, o Ministro Xavier de Albuquerque do Supremo Tribunal Federal, e o digno Prof. RomeU Pires de Campos BARROS.

Vossa vitória foi completa porque demonstrou aos desesperançados que o mérito pode prevalecer contra as manobras e as intrigas. E essa vitória teria sido impossível se não fósseis dotada de um caráter inquebrantável, de uma tenacidade ímpar, 
de uma coragem fora do comum. Esperavam, quem sabe, os vossos detratores que a campanha movida vos abalasse a força, vos toldasse a mente. Frágil como sois fisicamente, e feminina, supunham que desistiríeis do pleito, ou que vos pertubásseis a ponto de não resistir à cerrada interrogação da Banca ou de não poder, na aula, demonstrar a profundidade do saber e a clareza de pensamento. Nada disto ocorreu. Quem assistiu às provas, guarda a inolvidável lembrança de vosso domínio sobre a matéria e de vosso domínio sobre vós mesma.

Consagradora, pois, realmente foi a vitória. Consagração de uma carreira brilhante, consagração de uma lídima superioridade, consagração do mérito.

Com esta vitória, chegais, Profa. AdA Pellegrini GRINOVER, ao nível mais alto da carreira no magistério superior. Integrais, doravante, e plenamente, a Congregação da Faculdade de Direito do Largo de São Francisco. Vindes reforçá-la no exato instante em que ela perde, atingido pela cega lei da aposentadoria compulsória, um de seus mais eminentes mestres, o Prof. Miguel Reale. Fostes, como fui eu, aluna desse grande jurista e filósofo. Avaliais, portanto, o que significará, para essa Faculdade e para a Universidade de São Paulo, que ele, com descortino e segurança, regeu por duas vezes, essa falta.

$\mathrm{E}$ vindes reforçá-la num momento grave. Grave para a vida nacional. Grave para a vida universitária. Grave para a Faculdade de Direito.

Atravessando um período de transição política, sofre o Brasil o embate apaixonado dos partidarismos. Uma nuvem ideológica a muitos cega, ocultando a contemplação do supremo interesse da Pátria. Tudo é feito em nome da democracia, nada parece dever ser negado à democracia. Mas a invocação dos princípios sagrados de liberdade e de igualdade não basta para dar mérito àquilo que não tem intrinsecamente.

Não é com fanatismos, que se constrói uma democracia. Invoque-se a lição de MONTESQUIEU, para o qual a democracia não se implanta apenas com as instituições políticas. Reclama uma base social a ser criada pela educação e seu princípio, a virtude cívica. $\mathrm{E}$ virtude cívica quer dizer, o devotamento ao bem comum, que importa no respeito ao próximo e no senso do compromisso.

E não sobrevive a democracia se, uma vez implantada, promove a injustiça. Se a igualdade degenera em nivelamento, a liberdade em licença. "O excesso de liberdade", disse Platão, 
"conduz ao excesso de servidão". O caminho para a escravização totalitária, forma moderna e qualificada de tirania, passa pela anarquia.

A paixão política desvairada pertuba a Universidade e agora contamina a Faculdade. Não faltam os que atiçam estudantes contra professores, os que buscam tumultuar a vida da Universidade e da Faculdade movidos por desígnios, bem aparentes embora raramente confessados.

Onde deveria prevalecer o exame objetivo dos fatos, a análise fria dos argumentos, acaba por vencer a vociferação dos chavões, dos slogans. Ao trabalho e ao estudo se substituem as reuniões, assembléias, congressos em que só se ouvem as palavras de ordem e mais deslavadas formulações ideológicas. Em nome do estudo "crítico", cada vez menos se exerce o raciocínio crítico, cada vez menos se estuda. como se o conhecimento fosse inútil e bastasse a democracia, ou a revolução

Denuncia-se a falência das universidades. Nelas, nada se aprende, afirma-se. Mas pouco se aprende porque a paixão ideológica interrompe a toda hora o funcionamento das escolas, condena como alienado o aluno que estuda, denuncia e procura calar o professor que não adere ao "sentido da história" entrevisto pelos fanatizados. As reputações se fazem ou desfazem com o simplório julgamento: " $\mathrm{E}$ de direita" " $\mathrm{E}$ de esquerda" Como se isto significasse realmente alguma coisa de definido, exceto um posicionamento espacial. Se isto suprisse ou desculpasse a ignorância, se isto desse capacidade ou conhecimento, se isto fosse substituto adequado para a preocupação com a verdade, supremo valor do trabalho científico, portanto universitário.

Ora, a decadência do ensino acarreta a deterioração da profissão liberal, mesmo que outras causas não contribuissem, como contribuem, para tanto. $\mathbf{E}$ isto que não vêem certos líderes de classe, empenhados apenas e tão somente em ações e manifestações políticas.

Ponham-se de parte, porém, as preocupações que amargam. A ocasião é de regozijo.

Tenho mandato imperativo da douta Congregação para dar-vos Profa. ADA PELlegrini GRINOver as boas vindas. Os docentes da Academia se rejubilam por ver-vos alcançar, pelo mérito e pela tenacidade, o cargo de Professor Titular. E ao mesmo tempo confessam que muito esperam de vossa contribuição, para o ensino e $o$ destino da Faculdade. 
Exprimo também, agora sem designação expressa, em nome da turma de 1957 da Faculdade, à qual ambos pertencemos, o aplauso e as congratulações de todos os que foram vossos contemporâneos. Em todos os corações, vibra pela amiga que, vinda de tão longe, os conquistou, uma profunda estima e, por que não dizê-lo, um carinho profundo e puro.

Ouso aproveitar a ocasião para acrescentar a manifestação formal do meu contentamento. Há muito aprendi, cara Professora, a estimar-vos e à medida que melhor vos conheço, mais vos estimo. $\mathrm{E}$ isto que digo em nome pessoal certamente é subscrito pelos incontáveis amigos que aqui partilham da comemoração de vosso êxito.

Profa. Ada Pellegrini Grinover, esta é a mais alta investidura universitária mas não é um ponto final. Por isso exprimo o que vosso destino determina: Sempre mais alto, cada vez mais alto!

\section{A Nova Titular Agradece}

Descerram-se mais uma vez as portas deste salão nobre e um novo professor titular ultrapassa os seus umbrais. Solenemente, perante a Congregação reunida neste recinto nobre e vetusto, sob as vistas severas de Dom Pedro Segundo, o novo professor é recebido no seio dessa augusta assembléia.

Eis o sentido da cerimônia que nos reúne.

Mas, que se espera do novo titular? Talvez a manifestação do que lhe vai na alma - o orgulho, o respeito, a reverência, o júbilo, a gratidão, as mil emoções que o agitam? Talvez uma profissão de fé, uma promessa, um juramento? Ou a confirmação, talvez, de que a conquista foi merecida, não devendo esvair-se as esperanças nele depositadas?

Tudo isso eu me perguntei, debruçada sobre minh'alma, buscando no mais profundo âmago de mim mesma a resposta a essa indagação: que se espera de mim?

Mas o importante, senhores, não é o que se espera de mim agora, neste exato momento em que a emoção embarga a minha voz e os sentidos ofuscados obscurecem a mente. $O$ que importa é o que se espera de mim em atitudes e gestos, em palavras futuras, em comportamento e conduta.

Para tanto, é preciso saber, antes de mais nada, que representa a conquista do cargo de Professor Titular. 
Ser professor titular desta casa significa a inserção concreta nessa Douta Congregação, ou seja a participação integral e definitiva, pelo cargo mais elevado da carreira, em uma instituição secular. Instituição que é uma realidade jurídica permanente, estável em sua atuação e em suas tradições e ao mesmo tempo dinâmica e variável, para adaptar-se às necessidades mutantes. Essa instituição tem entre seus valores fundantes os melhores valores da própria sociedade: o humanismo, o vigor e a coragem das idéias, a luta pelo direito, pela justiça, pela liberdade.

Este é seu idealismo de ontem e de hoje. Por essas idéias morreu-se no passado; para essas idéias continuamos a viver.

Mas uma instituição somente sobrevive quando os que a integram se identificam com os princípios de sua existência e com as suas finalidades últimas. A instituição pressupõe a união de todos em torno do objetivo comum, pela adesão e pela colaboração, formando todos um só corpo, voltado à execução de seu ideário. Por isso, a instituição pode soçobrar frente às paixões dos homens, quando estes se afastam de conduta necessária à preservação do espírito institucional.

Cabe a nós cimentá-la pelas crenças e pelas realizações, para que ela permaneça, vigorosa e altaneira, resistindo aos ataques externos e internos dos que a vilipendiam. $O$ importante é termos sempre presentes os valores fundamentais dessa instituição, conjuntamente congregados e voltados à consecução de seus fins, para que possa ela sobreerguer-se acima das fraquezas de alguns, graças ao esforço de muitos.

E sempre presente a terei eu, que chego a essa Congregação ao cabo de uma áspera contenda que pretendeu alijar-me da disputa, desferindo-me o golpe mais rude que um profissional honrado pode sofrer: o golpe que visa a destruir toda uma carreira, edificada com esforço e dedicação, atacando-o na própria honra. Mas, enquanto me enxovalhavam, enquanto a difamação grassava aqui dentro e lá fora, eu tudo fazia para circunscrever o combate ao âmbito desta casa. Alguns terão confundido o silêncio com medo, a dignidade com apatia, a serenidade com fraqueza. Não importa. Altiva, conquanto ferida, eu buscava minhas forças na própria dimensão da instituição, que também fora ferida, e onde eu sabia que haveria de encontrar, mais cedo ou mais tarde, a luz da verdade e o consolo da justiça. A Faculdade, alta e sobranceira, reagiu e deu a sua resposta. E, dentro de seus princípios, também me consentiu dar a minha resposta. Eis a dimensão 
de nossa instituição, por cuja preservação havemos de lutar, para que como instituição sobreviva.

Tudo farei, senhores, para honrá-la sempre, custe o que custar, como fiz até agora.

Assim, quero que meu primeiro gesto, como membro legítimo dessa instituição de justiça, seja de conciliação para os que, de boa fé, me injustiçaram, sentindo-se futilmente derrotados com o coroamento dos longos anos em que dediquei o melhor de meus esforços à carreira universitária, toda ela realizada, à plena luz, nesta Faculdade de Direito: de onde, por minha obra exclusiva e pelo reconhecimento dos verdadeiros estudiosos, conquistei a posição que ocupo no cenário jurídico nacional.

Mas, se é esse o sentido da conquista do cargo de professor titular, qual o significado da cátedra de direito processual penal? Que se espera de mim, como sucessora de Joaquim Canuto Mendes de Almeida?

A renovação científica do direito processual, que se iniciara na Alemanha a partir da metade do século passado, tardou a penetrar no Brasil, onde os antigos processualistas continuavam ligados à velha escola procedimentalista, estudando o processo na dinâmica dos atos do procedimento e não a partir da conceituação de seus institutos. Todavia, a cátedra de processo civil, em São Paulo, sempre exerceu verdadeiro fascínio sobre os juristas, dado o prestígio dos que a ocuparam e o interesse pela matéria. JoÃo MonteIRo, ainda nos albores do século, já vislumbrava a ação como direito abstrato, erigindo-se em precursor, nesta Casa, da doutrina hoje geralmente aceita, aqui e alhures. A mesma intuição não se notava entre os cultores do processo penal, o qual iniciara sua renovação científica, ainda no século passado e sempre na Alemanha, com as obras de JoHN e VoN KRIES. E certo que os "Apontamentos sobre o processo criminal brasileiro", do grande Pimenta Bueno, são anteriores a esse período, assim como lhe são anteriores os "Elementos do Processo criminal", do Barão de Ramalho. Mas Galdino Siqueira, escrevendo sobre o processo e já neste século, não se afastaria da escola procedimentalista francesa, já superada na Europa, embora banhando-a dos ensinamentos dos praxistas portugueses, como Pereira e Sousa.

Antes disso, a cátedra de processo criminal de São Paulo havia adquirido expressão, pela primeira vez, quando de sua ocupação por JoÃo MENDES JR. Tratando do processo penal e 
do processo civil à luz de regras comuns, o Mestre notável da primeira República antecipava-se na edificação de uma teoria geral do processo, ciência que só hoje se afirma entre nós. Surgia ele, ainda, como precursor dos estudos constitucionais do processo, lançando as bases para a compreensão das garantias do "devido processo legal". E, além disso, edificava sua "teoria ontológica do processo", colocando a disciplina nos parâmetros da concepção aristotélico-tomista das quatro causas e daí estabelecendo a nítida distinção entre processso e procedimento.

Mas a lição de JoÃo MENDES JR. ficaria sem éco por longos anos. A doutrina processual brasileira de então ressentia-se profundamente de uma grande desatualização metodológica. Nossos estudiosos, habituados à leitura dos clássicos portugueses e dos exegetas francesses e italianos do século passado, não se haviam alinhado ao movimento de renovação que se instalara na Europa, faltando-lhes a visão orgânica do processo penal.

Somente com o ingresso no magistério de JOAQUIM CANUTO MENDES DE ALMEIDA o panorama modificar-se-ia, a partir da tese apresentada à Livre Docência - A Contrariedade na Instrução Criminal -, uma das obras-primas de nossa literatura processual. A conquista da cátedra, em 1938, assinalou uma nova fase e uma diversa postura, pela tentativa de se extraírem do velho processo criminal português princípios perenes, que estruturassem a jurisdição penal. Restaurador dos princípios informativos do processo tradicional, JOAQUIM CANUTO Mendes de AlmeidA, à semelhança de JoÃo MENDES JúnIoR, seu tio, preocupou-se com a perspectiva do "devido processo legal" e, com sapiência, sagacidade e força criadora, deixou sua marca indelével em muitos institutos da ciência processual. Basta recordar, entre tantos, o contraditório, o poder inquisitivo do juiz penal e, sobretudo, o enfoque do processo criminal como instrumento, não de persecução, e sim de liberdade jurídica do réu.

Concomitantemente, os tempos já haviam amadurecido para o ingresso do método científico na ciência processual civil brasileira. GABRIEL DE REZENDE FILHo, nesta Casa; MACHADo Guimarães, no Rio de Janeiro e, em Minas Gerais, AmflCAR DE CASTRO e LOPES DA COSTA, haviam iniciado a renovação metodológica que culminaria, em 1940, com a vinda à nossa academia de ENRICo TUllio LiEBMAN. Nos seis anos que esteve entre nós, admitido nesta Congregação como Professor visitante, foi ele o portador da moderna ciência européia do direito proces- 
sual. Fora aluno de CHIovendA, o mais prestigioso processualista italiano de todos os tempos, e conhecia profundamente a obra dos germânicos, a história do direito processual e o pensamento italiano da época, notadamente do genial CARNELUTTr. Além de ministrar aulas regulares nesta Casa, o mestre reunia estudiosos em sua residência para debaterem temas de direito processual. Foi assim que os jovens dos anos quarenta - Lufs Eulálio de Bueno Vidigal, Alfredo Buzaid, José Frederico MARQUES, BRUNo AFonso ANDRÉ, - se preparavam para dar início a uma verdadeira revolução processual, ligados por intima unidade de pensamento, a ponto de posteriormente seu movimento científico vir a ser denominado, por um autor estrangeiro, "Escola Processual de São Paulo"

A seguir, e ainda nesta Faculdade, JosÉ Frederico MARQUES, que havia estudado em conjunto o direito processual, civil e penal, dentro do conceito unitário da processualística, conquistava a livre docência, dando invulgar impulso, a partir da década de cinqüenta, aos modernos estudos de processo penal, iniciados no Rio de Janeiro, em 1945, com a obra de Hélio BASTOS TORNAGHI sobre a relação jurídica processual penal.

A partir daí, a renovação doutrinária do processo penal desenvolveu-se ininterruptamente, mercê das obras vigorosas de estudiosos como ROMEU PIRES DE CAMPOS BARRos, XAVIER DE Albuquerque, Athos Moraes Vellozo, Adhemar Raymundo DA Silva, Fernando DA Costa Tourinho Filho, Nilzardo CARneiro LeÃo e tantos outros. Mas, como observa JosÉ FrEDERICO MARQUES, "em São Paulo não se formou, em relação ao processo penal, aquela corrente de sucessivos mestres que de RAMALHo a GABRIEL DE REZENDE Filho construiu as bases, no processo civil, de uma perfeita "escola processual" - a escola processual de São Paulo".

Esse vício de origem projetou-se no presente, em que se podem indiscutivelmente apontar grandes processualistas penais, mas onde falta uma escola que os grandes processualistas aglutine em torno de certos pressupostos metodológicos fundamentais. Aliás, é esse um mal que parece macular o processo penal, aqui e alhures: já considerado por CARNELUTTI como a "gata borralheira" do direito processual, subordinado ora ao direito penal, ora ao direito processual civil, o processo penal, para MIGUEL FENECH, ainda há alguns anos continuava "huerfano de todo tratamiento cientifico" $\mathrm{E}$ enquanto na Itália o processo civil já há várias décadas havia ascendido à dignidade científica, GIROLAMo BELLAVISTA ainda entendia imprescindíveis ao processo penal "altre fatiche dogmatiche 
per potersi elevare alla stessa altezza di molte scienze giuridiche sorelle"

Douta Congregação. E nessas circunstâncias que ascendo à cátedra de processo penal e o faço consciente da recessidade imperiosa da formação de uma escola. Os grandes nomes, nós os temos. Falta, sem dúvida, uma figura humana e um homem de ciência como ENRICo TUlLIo LIEBMAN para promover e facilitar a aglutinação. Mas, com a ajuda de Deus, os seus alunos, e os alunos dos seus alunos, poderão tentar suprir a falta do Mestre. Pacificando dissidências, conciliando divergências, esquecendo desentendimentos, trazendo, enfim, para a disciplina aquele mesmo espírito institucional de adesão e colaboração a que antes me referi, será possível edificar um processo penal à altura das conquistas do processo civil. Para tanto, contamos com as lições do passado, com a genial intuição das raízes constitucionais do processo, de JoÃo MENDES JÚNIOR, com o enfoque de um processo penal inserido na teoria jurídica das liberdades públicas, de Joaquim Canuto Mendes DE Almeida. Para tanto, contamos com a institucionalização, nesta Casa, de uma teoria geral do processo, parte integrante do "curriculum" universitário e ministrada com grande proveito didático desde 1973: uma teoria geral do processo que, sem significar a identidade de seus ramos distintos, autoriza a elaboração científica de princípios gerais, informativos de todas as disciplinas processuais. E o enfoque do processo, unitariamente concebido, assume dimensão unívoca e altitude maior, graças à análise constitucional de seus institutos, examinados no quadro das liberdades públicas.

Assim como Joaquim Canuto Mendes DE Almeida foi "acusado" por um de seus examinadores de tentar o conúbio entre o então atualíssimo CARNELUTTI e o clássico JoÃo MENDES JÚNIOR, eu me proponho, Douta Congregação, a trabalhar, com afinco e denodo, na construção de uma verdadeira escola que, sem olvidar as lições do passado, opere com os olhos voltados para o futuro do processo penal. Para isso, meu talento é sem dúvida insuficiente. Mas eu trago no sangue as milenares tradições jurídicas de minha terra natal; trago no sangue a herança genética da vocação para o direito de meu bisavô, de meu avô, de meu pai; trago no sangue a fidelidade e a perseverança de minha mãe. $\mathrm{E}$ adquiri aqui, na minha pátria adotiva, o culto pelas tradições nacionais. Por isso, eu não pouparei esforços para difundir, destas Arcadas, o estudo do processo penal à luz de um método rigoroso, que exige uma postura dogmática mas também filosófica, porquanto requer que todo o direito, e conse- 
qüentemente também o processo, seja visto naquela tríplice dimensão descortinada pela sublime lição de Miguel REALE: fato, norma e valor. E o processo, na concepção axiológica de garantia dos direitos do homem, transcende assim o plano meramente técnico, para transformar-se em instrumento ético de liberdade e de justiça. Que nunca me faltem coragem e determinação para difundir essas idéias; que nunca me faltem empenho e seriedade para edificar uma verdadeira escola: não em torno de mim, que não tenho os predicados mínimos para tanto, mas em torno destas idéias, que são as idéias maiores do processo penal de hoje e de amanhã.

Um último aspecto cabe salientar. Este novo professor titular, que ascende hoje à cátedra de processo penal, é uma mulher. Qual o especial sentido dessa circunstância? Que se espera da mulher que alcança hoje o mais elevado cargo da carreira universitária, juntando-se àquela que, abrindo caminhos, será sempre a primeira entre nós - NAIR LEMOS GONÇALVES? Espera-se, Senhores, que traga ela a esta Douta Congregação, a esta augusta Casa, a participação ativa e responsável da expoente de uma tão considerável parcela de nossa sociedade. Que traga, em ação e em palavras, a sua cosmovisão, para que as mulheres e os homens, trabalhando e lutando lado a lado, juntos e se complementando, possam edificar um mundo melhor.

Por isso eu me dirijo aos jovens estudantes, aos meus colegas de Doutoral e de docência, aos advogados, aos promotores, aos juízes, às autoridades presentes. A compreensão há de vir deles. Mas dirijo-me, especialmente, às alunas e às colegas que se iniciam no magistério. A tenacidade há de ser delas.

Perceberão, às vezes, que precisam esforçar-se mais do que os homens, para atingir os mesmos resultados; sentirão, às vezes, que estão expostas aos olhos de todos, prontos a salientarem o menor defeito e a atribuí-lo à sua qualidade de mulher. Apesar disso, ou por isso mesmo, jamais se sirvam da condição de mulher como pretexto, como justificativa, como refúgio. Provem, com dignidade, com serenidade e com perseverança que, se somos profundamente diversas, não somos nem piores nem melhores do que os homens. Provem que a suavidade não se confunde com submissão, porque se a hora é de luta sabemos lutar. Que a sensibilidade não se confunde com sentimentalismo, porque se a hora é de decisão sabemos ser resolutas. Que a fragilidade não se confunde com fraqueza, porque se a hora é de trabalho sabemos trabalhar. E que 
sabemos ser fortes, sem sermos rudes; ser dignas, sem sermos soberbas; ser retas, sem sermos intolerantes. Não há conquista sem luta e sem responsabilidade. $E$ só através de uma luta elevada e digna poderá a mulher integrar-se por inteiro nas multifárias facetas da sociedade em que vive e pela qual é tão responsável quanto o homem.

E tempo de terminar. E só posso fazê-lo agradecendo.

Que o primeiro agradecimento seja para meu grande, meu querido amigo, MANOEL GONÇALVES FERREIRA FILHo, a quem eu já tanto devia e para quem acabo de assumir agora um débito ainda maior. Doce débito, esse, de reconhecimento e gratidão, tecidos de leal amizade e de afeto fraternal.

A profundidade de sua mensagem, a generosidade de suas palavras, a sinceridade de suas expressões, tocando as cordas mais sensíveis do meu ser, enaltecem muito mais quem as proferiu do que quem as recebe.

Agradeço a meus pais pelo legado maior que me deixaram: o legado do caráter, da retidão, da honestidade. Agradeço a meu filho, a quem pequeno ainda roubei tantas horas de convívio, e que me retribuiu com amor ainda maior, com a compreensão constante, com a solidariedade total, com a responsabilidade precoce, com a alegria e a bem-aventurança de seus vinte anos.

Agradeço a meus mestres, que nesta Casa me forjaram, apontando-me o caminho de sacrifícios, de altruismo, de dedicação que me traria até aqui. Obrigada, entre todos, Professor LUfS EULÁlio DE BUENo VIDIGAL, Mestre por antonomásia, por ter despertado em mim o amor à ciência processual, por ter-me estimulado sempre, por ter-me acostumado, cedo ainda, à pesquisa e ao esforço pessoal, por ter-me familiarizado, desde os bancos acadêmicos, com o rigoroso método científico que sempre plasmou suas aulas, simples e profundas, e suas obras, modernas e criativas.

Agradeço ao pessoal administrativo desta Faculdade, que em grande parte vem acompanhando meus passos desde os tempos de estudante, apoiando-me sempre e sempre com o seu calor humano.

Agradeço aos meus alunos, sem os quais não se justificaria minha presença aqui, alunos que em todas as circunstâncias responderam à honestidade de propósitos com interesse, entusiasmo, seriedade e carinho e que; ainda há poucos dias, ao se encerrarem as provas do concurso, souberam prestar a homenagem mais expressiva que um professor pode receber. 
Agradeço a meus inimigos, cuja sanha me fortaleceu, cuja inveja me temperou, cujos ataques despertavam, a cada golpe, um novo e leal amigo. $E$ agradeço sobretudo a esses amigos, aos quais devo a minha persistência e a minha vitória. A esses amigos que, fisicamente ou me acompanhando de longe, mais uma vez dizem "presente" Amigos devotados e desprendidos, que me apoiaram nos momentos difíceis, que me ampararam quando o espírito fraquejava, que me animaram quando a luta era mais árdua. Sem eles - e são tantos - as barreiras teriam sido intransponíveis, as pedras do caminho ásperas demais, os sobressaltos da estrada insuportáveis.

Eram os dias da amargura e da humilhação. Eu elevava a Cristo uma prece, sob forma de poesia. Essa prece terminava assim:

"Aceito o sofrimento.

Aceito essa injustiça. Aceito a provação.

E as ergo para Cristo.

Mas, tende compaixão.

Não permitais, Senhor, que o espírito esmoreça.

Dai-me forças, Senhor, para seguir lutando.

Se não por mim, ó Deus, ao menos por aqueles que me deram sua mão, que acreditam em mim e vão me sustentando" 